\title{
KONDISI SOSIAL EKONOMI MASYARAKAT PETANI DESA LAPANGISI KECAMATAN MOWEWE KABUPATEN KOLAKA TIMUR
}

\author{
La Nur Muhammad Iskandar Patola ${ }^{1}$ \\ ${ }^{1}$ Program Studi Pendidikan Geografi, Universitas Halu Oleo, Kendari.
}

\begin{abstract}
Abstrak : Penelitian ini berjudul Kondisi Sosial Ekonomi masyarakat petani di Desa Lapangisi Kecamatan Mowewe Kabupaten Kolaka Timur, yang dilihat dari beberapa indikator sesuai dengan BPS 2016 yaitu, aspek pendidikan, perumahan, kesehatan dan pendapatan. Penelitian ini bertujuan untuk mengetahui kondisi sosial masyarakat petani, untuk mengetahui kondisi ekonomi masyarakat petani, dan untuk mengetahui sosial ekonomi masyarakat petani di Desa Lapangisi Kecamatan Mowewe Kabupaten Kolaka Timur. Jenis penelitian ini adalah penelitian deskriktif kualitatif.Penentuan informan dalam penelitian ini adalah menggunakan teknik purposive sampling berdasarkan kriteria dan pertimbangan tertentu.Teknik pengumpulan data yang di gunakan yaitu melalui obserfasi, wawancara, dan dokumentasi.Dari populasi 535 jiwa ditentukan informan sebanyak 23 kepala keluarga (KK).Teknik analisisnya menggunakan teknik analisis data deskriptif dan disajikan pada tabel distribusi frekuensi. Hasil penelitian meliputi: 1) Kondisi pendidikan formal masih rendah, sebagian besar hanya sampai tingkat sekolah dasar dan sekolah menengah pertama, dan hanya sebagian kecil saja yang pernah mengikuti pendidikan non-formal yaitu delapan orang (34 \%) pendidikan kepala keluarga masyarakat petani pada tingkat sekolah menengah atas. 2) kondisi perumahan masyarakat petani Desa Lapangisi sudah di kategorikan sedang. 3) Kondisi kesehatan adalah hanya sebagian kecil keluarga petani menderita penyakit flu dan demam 2 orang. 4) Kondisi pendapatan adalah jumlah pendapatan dihitung berdasarkan pengeluaran. Rata-rata pendapatan yang diterima oleh keluarga petani Desa Lapangisi adalah sebesar Rp. 2.500.000 s/d Rp. 4.000.000 Berdasarkan indikator tersebut secara umum di ketahui bahwa taraf hidup masyarakat petani Desa Lapangisi Kecamatan Mowewe Kabupaten Kolaka Timur adalah tergolong kategori sejahtera.
\end{abstract}

Kata kunci : Kondisi Sosial Ekonomi, Masyarakat Petani 


\title{
Socio-Economic Condition, Farmers Community Lapangisi Village Mowewe Subdistrict East Kolaka District
}

\author{
La Nur Muhammad Iskandar Patola ${ }^{1}$
}

\begin{abstract}
This research entitled Socio-Economic Condition of farmer communities in Lapangisi Village, Mowewe Sub-District, East Kolaka District, which is seen from several indicators in accordance with BPS 2016 namely, education, housing, health and income aspects. This study aims to determine the social conditions of farmers communities, to determine the economic conditions of farmers' communities, and to determine the socio-economic community of farmers in the Village District Lapangisi Mowewe East Kolaka District. This type of research is qualitative descriptive research. Determination of informants in this study is to use purposive sampling technique based on certain criteria and considerations. Data collection techniques in use are through obserfasi, interviews, and documentation. Of the population of 535 souls, 23 informants were assigned by the informants. Analytical techniques using descriptive data analysis techniques and presented in the frequency distribution table. The results of the study include: 1) The formal education condition is still low, mostly only up to primary and junior high school levels, and only a small proportion have attended non formal education ie eight people (34\%) education of farmers' on. 2) housing conditions of Lapangisi Village farmers are already moderately categorized. 3 ) The health condition is only a small percentage of farm families suffering from flu and fever 2 people. 4) The condition of income is the amount of income calculated based on expenditure. The average income received by Lapangisi Village Farmer's family is Rp. 2,500,000 s / d Rp. 4.000.000 Based on these indicators generally in the know that the living standard of farmers in Lapangisi Village, Mowewe Sub-District, East Kolaka Regency is classified as prosperous category.
\end{abstract}

\section{Keywords: Socio-Economic Condition, Farmers Community}

\section{PENDAHULUAN}

Pembangunan nasional merupakan sebagai proses yang berkesinambungan dalam upaya untuk meningkatkan kualitas manusia dan masyarakat Indonesia secara terencana dan terarah di setiap bidang kehidupan. Pembangunan juga harus dapat meningkatkan taraf hidup dan perekonomian yang sehat yaitu perekonomian yang mampu menjaga kesinambungan dari satu generasi ke generasi berikutnya.Sehingga pada masa mendatang dapat menciptakan pertumbuhan ekonomi yang dinamis menuju perubahan struktur yang seimbang, meningkatkan kesejahteraan dan mengurangi kemiskinan, tanpa merusak sumber daya alam dan lingkungan.

Pembangunan pertanian pada dasarnya merupakan salah satu aspek yang sangat penting untuk keberlansungann hidup manusia guna untuk menunjang kebutuhan ekonominya. Sebagaimana yang di katakan oleh A. T. Mosher (1968), bahwa pembangunan pertanian adalah suatu bagian integral dari pada 
pembangunan ekonomi dan masyarakat secara umum.

Dengan demikian diperlukan berbagai upaya guna meningkatkan roda perekonomian masyarakat terutama bagi masyarakat yang hidup di perdesaan, dimana masyarakanya secara umum masih mempunyai tingkat pendapatan dan kehidupan yang masih rendah. Oleh karena itu, semua aktivitas ekonomi harus mendapat perhatian dan harus di upayakan secara berkesinambungan agar dapat mendorong peningkatan pendapatan perkapita masyarakat petani di perdesaan.

Uraian tersebut kita dapat menarik kesimpulan bahwa pembangunan dapat merubah pola pikir masyarakat dalam mengelola sumber daya yang ada serta memperhatikan tantangan perkembangan global dengan cara memanfaatkan kemajuan ilmu pengetahuan dan teknologi. Artinya bahwa masyarakat di pacu untuk dapat mengelola sumber daya yang ada dengan sebaik-baiknya demi untuk meningkatkan taraf hidup yang lebih baik.

Berdasarkan data di Desa Lapangisi memiliki jumlah penduduk sebanyak 535 jiwa dengan jumlah Kepala Keluarga sebanyak 144.Masyarat Desa Lapangisi sebagian besar bermata pencaharian sebagai petani karena di wilayah Desa Lapangisi memiliki tanah yang subur dan sangat cocok untuk lahan pertanian oleh karena itu banyak masyarakat Desa Lapangisi yang menggantungkan hidupnya dari hasil pertanian salah satunya adalah petani sawah.Seperti yang kita ketahui bersama dari tahun ketahun harga bahan pangan semakin melonjak, harganyapun tentu sangat menguntungkan bagi para petani karena dari hasil panen mereka selain untuk di konsumsi sendiri, juga dapat di jual untuk membangun dan membiayai keluarganya.

Menurut Dalyono (2005), kondisi sosial adalah semua orang atau manusia lain yang mempengaruhi kita, meliputi : perubahan sosial, tingkatan sosial, dan apa saja yang ada dalam kehidupan sosial. Hal ini berarti bahwa lingkungan sosial juga mempengaruhi pencapaian pendidikan, sosial ekonomi, dan interaksi sosial.Sesejalan dengan pendapat Melly (2001), sosial ekonomi dapat dilihat dari pekerjaan, pendidikan kesehatan dan pemenuhan kebutuhan hidup dalam rumah tangga. Berdasarkan teori tersebut masyarakat dapat di golongkan berdasarkan kedudukan sosial ekonomi atas, kedudukan sosial ekonomi menengah dan sosial ekonomi kebawah.

Menurut Syam (1980), menjelaskan bahwa pendidikan adalah suatu lembaga dalam tiap-tiap masyarakat yang beradap tetapi tujuan pendidikan tidaklah sama dalam setiap masyarakat dan tujuan-tujuan pendidikan di dasarkan pada prinsipprinsip (nilai-nilai) cita-cita dan fasilitas yang berlaku dalam masyarakat. Selanjutnya menurut Purwanto (1987), pendidikan adalah segala usaha yang dilakukan orang dewasa dalam pergaulan dengan anakanak untuk memimpin perkembangan jasmani dan rohaninya ke arah kedewasaan atau lebih jelasnya pendidikan adalah pimpinan yang diberikan dengan sengaja oleh orang dewasa kepada anak-anak dalam pertumbuhannya (jasmani dan rohaninya) agar berguna bagi diri sendiri dan bagi masyarakat.

Perumahan merupakan salah satu bentuk sarana hunian yang memiliki kaitan yang sangat erat 
dengan masyarakatnya.Hal ini berarti perumahan di suatu lokasi sedikit banyak mencerminkan karakteristik masyarakat yang tinggal di perumahan tersebut (Abrams, 1964). Sedangkan menurut Yudhohusodo (1991), perumahan dapat diartikan sebagai suatu cerminan dari diri pribadi manusia, baik secara perorangan maupun dalam suatu kesatuan dan kebersamaan dengan lingkungan alamnya dan dapat juga mencerminkan taraf hidup, kesejahteraan, kepribadian, dan peradaban manusia, masyarakat ataupun suatu bangsa.

Defenisi kesehatan menurut Badan Pusat Statistik (BPS : 2016) adalah hak asasi manusia dan salah satu unsur kesejahteraan yang harus diwujudkan sesuai dengan cita-cita bangsa Indonesia sebagaimana dimaksud dalam Pancasila dan Undang-Undang Dasar Negara Republik Indonesia Tahun 1945. Untuk mencapai tujuan nasional tersebut maka pemerintah perlu melakukan upaya pembangunan kesehatan.Pembangunan kesehatan merupakan investasi utama bagi pembangunan sumber daya manusia Indonesia.Pembangunan kesehatan pada dasarnya adalah upaya untuk meningkatkan kesadaran, kemauan, serta kemampuan setiap orang untuk dapat berperilaku hidup yang sehat untuk mencapai derajat kesehatan masyarakat yang setinggitingginya.Untuk mewujudkan hal tersebut, perlu perencanaan pembangunan kesehatan yang sistematis, terarah, terpadu dan menyeluruh, serta dibutuhkan keterlibatan berbagai sektor dan seluruh komponen bangsa dalam pelaksanaannya.

$$
\text { Pengertian pendapatan }
$$

menurut Dyckman (2002), bahwa pendapatan adalah "arus masuk atau peningkatan lainnya atas aktiva sebuah entitas atau penyelesaian kewajiban selama satu periode dari pengiriman atau produksi barang, penyediaan jasa, atau aktivitas lain yang merupakan operasi utama atau sentral entitas yang sedang berlangsung". Pengertian pendapatan menurut Niswonger (1999), memberikan penekanan pada konsep pengaruh terhadap ekuitas pemilik, yaitu "pendapatan (revenue) adalah peningkatan ekuitas pemilik yang diakibatkan oleh proses penjualan barang dan jasa kepada pembeli.

Menurut Suelisyo dalam Ekawarna (2010), ilmu ekonomi sebagai ilmu yang mempelajari bagaimana orang dan masyarakat menentukan pilihan mengenai penggunaan sumber daya yang langkah dan mempunyai penggunaan alternatif untuk menghasilkan barang dan jasa serta mendistribusikannya hanya untuk konsumsi berbagai orang dan kelompok yang terdapat dalam masyarakat. Ilmu ekonomi di artikan sebagai ilmu yang mempelajari bagaimana tingkah laku manusia baik secara perorangan atau masyarakat berusaha memenuhi kebutuhan mereka sebagai alat pemuas kebutuhan atau sumberdaya yang terbatas adanya (Suparmako, 2008).

Berdasarkan pendapat Soekanto (1990), petani merupakan semua orang yang berdiam di pedesaan yang mengelola usaha pertanian yang membedakan dengan masyarakat lainnya adalah faktor pemilikan tanah atau lahan yang dimilikinya.

Hasil penelitian yang relevan dalam penelitian ini adalah Penelitian Wulandari (2013), yaitu dengan judul Kondisi Sosial Ekonomi Petani Padi Sawah Di Kelurahan Mangalli Kecamatan Pallangga Kabupaten 
Gowa.Penelitian inibertujuan untuk mengetahui bagaimana kondisi pola hubungan sosial pada petani padi sawah. Kegunaan penelitian ini diharapkan agar dapat member sumbangsih kepada Kelurahan Mangalli, supaya pemerintah daerah memperhatikan petani sawah yang ada di desa tersebut.Berdasarkan hal itu maka dibahas didalam rumusan masalah yang meliputi bagaimana pola hubungan sosial yang terjadi antara petani pemilik dan petani penggarap pada petani sawah di Kelurahan mangalli Kecamatan Pallangga Kabupaten Gowa. Untuk mencapai tujuan tersebut, maka peneliti menggunakan pendekatan kualitatif dengan dasar penelitian yaitu studi kasus dan sumber data primer yaitu melalui wawancara, observasi dan teknik lain. Dengan mengunakan metode kualitatif, adapun lokasi penelitian di Kelurahan Mangalli Kabupaten Gowa. Penunjukan didasarkankarena pada kecamatan ini banyak petani sawah kecil yang cenderung masih mengalami kemiskinan. Dalam penelitian ini, desain yang digunakan adalah desain studi kasus tentang Pola hubungan sosial Pada Masyarakat di Kelurahan Mangalli, dan tipe penelitian yang digunakan yaitu secara deskriktif. Adapun hasil penelitian ini yang melandasi penyebab kemiskinan pada petani sawah adalah meningkatnya faktor kebutuhan hidup keluarga yang tidak seimbang dengan penghasilan mereka, sehingga mempengaruhi pola kehidupan para petani sawah, hal ini dapat dilihat dari penghasilan mereka dan pola hidup para petani. Dan yang menjadi penghambat para petani sawah dalam mengatasi kemiskinan ialah kurangnya perhatian pemerintah setempat dalam memberikan solusi atau bantuan bagi para petani untuk meningkatkan hasil panen mereka dan juga para petani dalam teknik pengelolaan sawah.

\section{METODE PENELITIAN Lokasi Dan Waktu Penelitian}

Peneltian ini dilakukan di Desa Lapangisi Kecamatan Mowewe Kabupaten Kolaka Timur pada tanggal 3 s/d 22 April 2018.

\section{Populasi peneitian}

Populasi dalam penelitian ini adalah kepala keluarga masyarakat Desa Lapangisi Kecamatan Mowewe Kabupaten Kolaka Timur yang berjumlah 114 kepala keluarga (KK).

\section{Sampel penelitian}

Menurut Arikunto (2006), jika popolasi kurang dari 100 maka sampel diammbil seluruhnya, dan apabila populasi lebih dari 100 maka dapat di ambil sampel sebesar $10-15 \%$ atau 20 - 25\%. Dalam penelitian ini akan di ambil sampel sebesar $20 \%$ dari total populasi.

$\frac{20}{100} X 114=22,8$

22,8 dibulatkan menjadi 23 informan. Jadi, jumlah sampel yang di ambil sebanyak 23 informan untuk mewakili 114 kepala keluarga (KK) di Desa Lapangisi Kecamatan Mowewe Kabupaten Kolaka Timur.

Pengambilan sampel dalam penelitian ini yaitu menggunakan Teknik penentuan informan dalam penelitian ini adalah menggunakan teknik purposive sampling berdasarkan kriteria dan pertimbangan tertentu. Adapun informan penelitian ini ditetapkan sejumlah 23 informan yang terdiri dari informan kunci dan informan pokok. Informan kunci terdiri dari Kepala Desa, petani yang 
memiliki status sosial ekonomi yang relatif tinggi, petani yang memilki status sosial ekonomi menengah dan petani yang memilki status sosial ekonomi menengah kebawah.

\section{Jenis Penelitian}

Jenis penelitian ini adalah jenis penelitian deskriptif kulitatif.Penelitian diskriptif kualitatif adalah suatu bentuk penelitian yang ditujukan untuk mendeskripsikan fenomena-fenomena yang ada, baik fenomena alamiah maupun fenomena buatan manusia.Fenomena itu bisa berupa bentuk, aktivitas, karakteristik, perubahan, hubungan, kesamaan, dan perbedaan antara fenomena yang satu dengan fenomena lainnya (Sukmadinata, 2006).

\section{Fokus Penelitian}

Berdasarkan permasalahan penelitian, maka penetapan fokus penelitian ini adalah tentang kehidupan masyarakat patani dalam ruang lingkup kajiannya tentang kondisi sosial ekonomi masyarakat petani di Desa Lapangisi Kecamatan Mowewe Kabupaten Kolaka Timur.

\section{Defenisi Konseptual}

Definisi konseptual dalam penelitian ini adalah untuk memperjelas unsur-unsur yang diteliti sebagai berikut:

a. Kondisi sosial adalah keadaan kehidupan sosial yang berhubungan dengan pemenuhan kebutuhan : (1) Pendidikan, (2) Perumahan, (3) Kesehatan, (4) Pendapatan.

b. Kondisi ekonomi adalah keadaan suatu tingkatan persentase ekonomi tentang: (1) Produksi, Distribusi, (3) Konsumsim.

\section{Jenis Data}

Jenis data yang dibutuhkan dalam penelitian ini adalah data kualitatif dan kuantitatif, yang bersumber dari data primer dan sekunder. Data primer diperoleh melalui wawancara mendalam pada informan. Data sekunder penelitian ini diperoleh dari dokumen-dokumen seperti, data penduduk, jumlah Kepala Keluarga petani, luas wilayah, jumlah produksi usahatani, jumlah kelompok tani, dan lain-lain sesuai kebutuhan data yang dapat menunjang penulisan hasil penelitian.

\section{Teknik Pengumpulan Data}

Teknik pengumpulan data penelitian ini yaitu:Observasi. Wawancara, dan Dokumentasi.

\section{Instrumen/Bahan dan Alat Penelitian}

Instrumen/bahan dan alat penelitian dalam penelitian ini adalah (1) catatan lapangan observasi diperoleh dengan menggunakan matriks observasi.; dan (2) panduan pertanyaan wawancara.

\section{Teknik Analisis Data}

Teknik analisis data dalam penelitian ini adalah teknik analisis data deskriptif, melalui tahapan teknik analisis interaktif Miles \& Huberman yang terdiri dari tiga alur kegiatan yang terjadi bersamaan, yaitu reduksi data, penyajian data dan penarikan kesimpulan/verifikasi Miles dan Huberman (1992).

\section{Indikator Penelitian}

Dalam
pengamatan serta memberikan
penilaian mengenai kondisi sosial
ekonomi masyarakat selalu didasarkan
pada indikator-indikator penelitian


Badan Pusat Statistik yang sifatnya fisik dan non-fisik sehingga menggambarkan kondisi yang sesungguhnya (badan pusat statistik, 2016).

\section{GAMBARAN UMUM LOKASI PENELITIAN}

\section{Letak dan Luas Wilayah}

Desa Lapangisi salah satu desa wilayah dari sepuluh desa/kelurahan yang ada di Kecamatan Mowewe Kabupaten Kolaka Timur.Yang merupakan pemekaran dari desa kelurahan Horodopi pada tahun 2008 secara administratif wilayah desa lapangisi berbatsan dengan daerah-daerah sebagai berikut:

Gambaran batas wilayah Desa Lapangisi Kecamatan Mowewe Kabupaten Kolaka Timur tersebut jika dilihat dari aspek sosial ekonomi, maka Desa Lapangisi memiliki kecenderungan akan mengalami percepatan pembangunan pada berbagai sektor. Desa Lapangisi memiliki luas wilayah $\pm 8,29 \mathrm{~km}^{2}$.
Berdasarkan data di Desa Lapangisi memiliki jumlah penduduk sebanyak 535 jiwa dengan jumlah Kepala Keluarga sebanyak 144.Masyarat Desa Lapangisi sebagian besar bermata pencaharian sebagai petani karena di wilayah Desa Lapangisi memiliki tanah yang subur dan sangat cocok untuk lahan pertanian oleh karena itu banyak masyarakat Desa Lapangisi yang menggantungkan hidupnya dari hasil pertanian.

\section{Identitas Informan \\ Jenis Kelamin Informan}

Sesuai dengan sampel penelitian yang telah di bahas pada bab sebelumnya bahwa yang menjadi informan adalah masyarakat petani padi sawah desa lapangisi kecamatan mowewe kabupaten kolaka timur yang berjumlah 23 orang, Untuk lebih jelasnya mengenai jenis kelamin informan dapat di lihat pada tabel di bawah ini :

\section{Tabel 3.1Identitas Informan Berdasarkan Jenis Kelamin}

\begin{tabular}{ccccc}
\hline No & Jenis kelamin informan & Jumlah (orang) & Persentase $(\%)$ & Kategori \\
\hline 1. & Laki-laki & 22 & 96 & Tinggi \\
\hline 2. & Perempuan & 1 & 4 & Rendah \\
\hline & Jumlah & 23 & $100 \%$ & - \\
\hline
\end{tabular}

Sumber: Data Primer Diolah,2018

Berdasarkan penelitian dengan menyebar kuesioner yang telah di ketahui bahwa informan yang lebih banyak adalah laki-laki sebanyak 22 informan dengan jumlah persentase 96\% dan perempuan sebanyak 1 informan dengan jumlah persentase $4 \%$.

\section{Umur Informan}

Untuk umur informan dapat di lihat pda table di bawah ini.

Tabel 3.2Identitas Informan Berdasarkan Umur

\begin{tabular}{ccccc}
\hline No & Umur informan & Jumlah (orang) & Persentase $(\%)$ & Kategori \\
\hline 1 & $20-30$ & 1 & 4 & Rendah \\
\hline 2 & $31-40$ & 4 & 17 & Sedang \\
\hline 3 & $41-50$ & 18 & 79 & Tinggi \\
\hline
\end{tabular}




\begin{tabular}{ccc}
\hline Jumlah & 23 & $100 \%$ \\
\hline & & Sumber: Data Primer Diolah,2018
\end{tabular}

Berdasarkan tabel di atas menunjukan bahwa umur informan yang paling banyak yaitu berumur 41 50 tahun keatas yaitu sebanyak 18 orang informan dengan persenttase $79 \%$ dan yang berumur 31-40 yaitu sebanyak 4 orang informan dengan jumlah persentase $17 \%$ dan yang berusia 20-30 adalah jumlah informan yang paling sedikit yaitu sebanyak 1 orang informan dengan jumlah persentasi $4 \%$.

\section{HASIL DAN PEMBAHASAN}

Berdasarkan hasil analisis data berikut ini disajikan deskripsi hasil penelitian mengenai Kondisi Sosial Ekonomi Masyarakat Petani Desa Lapangisi Kecamatan Mowewe Kabupaten Kolaka Timur.

\section{Hasil Penelitian Tingkat Pendidikan Formal}

Salah satu indikator kondisi sosial ekonomi masyarakat dapat dilihat dari aspek pendidikan yang mereka miliki, sebab dengan faktor pendidikan dapat menentukan setiap tindakan terutama dalam penyerapan tenaga kerja. Tingkat pendidikan juga dapat mempengaruhi cara berpikir seseorang dalam mengambil keputusan ketika melakukan kegiatan. Tingkat pendidikan yang di maksud dalam penelian ini adalah jenjang pendidikan formal yang telah dilalui oleh informan.

Berdasarkan hasil penelitian dilapangan menunjukan bahwa tingkat pendidikan informan masih di kategorikan rendah. Mengenai tingkat pendidikan informan secara umum dapat di lihat pada tabel berikut:

Tabel 4.1Tingkat Pendidikan Informan

\begin{tabular}{ccccc}
\hline No & Tingkat Pendidikan & Jumlah Informan & Presentasi $(\%)$ & Kategori \\
\hline 1 & SD & 10 & 44 & Rendah \\
\hline 2 & SMP & 5 & 22 & Rendah \\
\hline 3 & SMA & 7 & 30 & Sedang \\
\hline 4 & PT & 1 & 4 & Tinggi \\
\hline & Jumlah & 23 & 100 & - \\
\hline
\end{tabular}

Sumber: Data Primer Diolah,2018

Sebagaimana yang ditunjukkan dalam tabel di atas terlihat bahwa, informan masyarakat petani di Desa Lapangisi Kecamatan Mowewe Kabupaten Kolaka Timur mayoritas petani memiliki tingkat pendidikan yang masih relatif rendah yaitu berkisar antara tamat Sekolah Dasar (SD) sampai dengan Tamatan Perguruan Tinggi (PT). Banyaknya jumlah informan yang menyelesaikan pendidikan formal di tingkat Sekolah
Dasar (SD) sebanyak $10 \mathrm{KK}$ atau dengan tingkat persentase $44 \%$, sedangkat informan dengan tingkat pendidikan Sekolah Menengah Pertama (SMP) sebanyak $5 \mathrm{KK}$ atau dengan tingkat persentase $22 \%$, sementara informan untuk jenjang poendidikan Sekolah Menengah Atas (SMA) berjumlah $7 \mathrm{KK}$ dengan tingkat persentase $30 \%$, sedangkan untuk tingkat perguruan tinggi hanya 1 
informan dengan persentase sebesar $4 \%$.

Dengan demikian sebagian besar informan rata-rata mempunyai pendidikan formal pada tingkat Sekolah Dasar (SD).Hal ini dapat menunjang tingkat pemahaman masyarakat dari berbagai bidang kegiatan pembangunan.Dari penjelasan tersebut di atas terlihat bahwa tingkat pendidikan informan dapat ditarik kesimpulan yaitu, rendahnya tingkat pendidikan yang di miliki oleh masyarakat petani padi sawah di desa lapangisi kecamatan mowewe kabupaten kolaka timur menyebabkan rendahnya kesempatan kerja yang dapat dicapai keluarga tersebut.

\section{Kondisi Perumahan Informan Status Kepemilikan Rumah}

Rumah merupakan salah satu kebutuhan pokok bagi kehidupan manusia dimana rumah juga sebagai kebutuhan dasar yang harus di penuhi oleh makhluk yang berpikir, karena rumah tidak hanya sekedar pemenuhan kebutuhan tempat tinggal atau berlindung saja akan tetapi di selaraskan dengan kebutuhan lain seperti tempat beristirahat, tempat berkumpul dengan keluarga dan sebagai lambang status sosial dalam lingkungan masyarakat sekitarnya.

Berdasarkan hasil penelitian di lapangan menunjukan bahwa status kepemilikan rumah yang di tempati oleh informan adalah milik sendiri. Untuk lebih jelasnya mengenai status kepemilikan rumah yang di tempati oleh informan dapat di lihat pada tabel sebagai berikut:

Tabel 4.2Status Kepemilikan Rumah Informan

\begin{tabular}{ccccc}
\hline No & Status Kepemilikan & Jumlah (Orang) & Persentase (\%) & Kategori \\
\hline 1 & Milik Sendiri & 22 & 96 & Tinggi \\
\hline 2 & Sewa & - & - & - \\
\hline 3 & Menumpang & 1 & 4 & Rendah \\
\hline & Jumlah & 23 & 100 & - \\
\hline
\end{tabular}

Tabel di atas menunjukan bahwa status kepemilikan rumah yang di tempati oleh informan dimana dari 23 informan yang memiliki rumah sendiri sebanyak 22 orang informan atau sebesar 96\%, sedangkan 1 informan atau sebesar $4 \%$ adalah menumpang, dalam artian informan ini sudah mempunyai keluarga namun mereka belum mempunyai rumah sendiri atau dengan kata lain mereka masih tinggal bersama orang tuanya.

\section{Luas Bangunan Rumah}

Selain aspek kepemilikan rumah informan, hal yang dapat di lihat dari aspek perumahan yaitu kondisi rumah yang dimiliki informan. Adapun luas bangunan rumah yang dimiliki informan dapat dilihat pada tabel berikut:

Tabel 4.3Luas Bangunan Rumah Informan

\begin{tabular}{ccccc}
\hline No & $\begin{array}{c}\text { Luas Bangunan } \\
\text { Rumah }\left(\mathrm{M}^{2}\right)\end{array}$ & Jumlah (Orang) & Persentase $(\%)$ & Kategori \\
\hline 1 & $40-70$ & 9 & 39 & Rendah \\
\hline
\end{tabular}




\begin{tabular}{ccccc}
2 & $71-101$ & 9 & 39 & Sedang \\
\hline 3 & $102-131$ & 5 & 22 & Tinggi \\
\hline & Jumlah & 23 & 100 & - \\
\hline
\end{tabular}

Sumber : Data Primer Diolah, 2018

Berdasarkan tabel diatas menunjukan bahwa yang memiliki luas bangunan rumah sebesar $40-70$ $\mathrm{M}^{2}$ yaitu sebanyak 9 informan dengan persentase sebesar $39 \%$, senjutnya informan yang memiliki rumah berukuran $71-101 \mathrm{M}^{2}$ adalah sebanyak 9 informan dengan persentase $39 \%$, sedangkan yang memiliki luas bangunan rumah sebesar
$102-131 \mathrm{M}^{2}$ dengan jumlah persentase $22 \%$. Hal ini menunjukan bahwa umumnya infonforman memiliki luas bangunan rumah rendah.

\section{Jenis dinding rumah}

Untuk mengetahui lebih jelasnya mengenai rumah yang di tempati oleh informan dapat dilihat pada tabel berikit:

Tabel 4.4Dinding Rumah Informan

\begin{tabular}{ccccc}
\hline No & Dinding Rumah & Jumlah (Orang) & Persentase $(\%)$ & Kategori \\
\hline 1 & Beton & 4 & 17 & Tinggi \\
\hline 2 & Papan & 19 & 83 & Sedang \\
\hline 3 & Bambu & - & - & - \\
\hline & Jumlah & 23 & 100 & - \\
\hline
\end{tabular}

Sumber :Data Primer Diolah, 2018

Tabel tersebut di atas menunjukan bahwa jumlah informan yang memiliki dinding beton (tembok) adalah 4 informan atau sebesar $17 \%$, sedangkan yang memiliki rumah berdinding papan adalah 19 informan atau sebesar $83 \%$ dan rumah yang berdindingkan bamboo tidak ada untuk di Desa Lapangisi.

Berdasarkan penjelasan di atas menunjukan bahwa perumahan masyarakat petani padi di desa lapangisi kecamatan mowewe kabupaten kolaka timur sudah $79 \%$ memiliki rumah berdinding papan sehingga bisa di kategorikan sedang.

\section{Jenis atap rumah}

Dari hasil penelitian yang di lakukan, peneliti melihat kondisi atap rumah informan yaitu sakura, seng dan rumbia hal ini dapat dilihat pada tabel berikut :

Tabel 4.5Kondisi Atap Rumah Informan

\begin{tabular}{ccccc}
\hline No & Kondisi Atap & Jumlah (Orang) & Persentasi $(\%)$ & Kategori \\
\hline 1 & Sakura & 3 & 13 & Tinggi \\
\hline
\end{tabular}




\begin{tabular}{ccccc}
2 & Seng & 20 & 87 & Sedang \\
\hline 3 & Rumbia & - & - & - \\
\hline & Jumlah & 23 & 100 & - \\
\hline
\end{tabular}

Sumber: Data Primer Diolah, 2018

Berdasarkan tabel di atas menunjukan bahwa sebagian besar rumah informan beratapkan seng sebanyak 20 informan dengan jumlah persentase $87 \%$ dan rumah informan yang beratapkan sakura berjumlah 3 informan dengan jumlah persentase $13 \%$.

\section{Jenis lantai rumah informan}

Selain aspek kepemilikan rumah, luas bangunan, dinding rumah, dan jenis atap rumah, hal yang dapat di perhatikan dari aspek perumahan yaitu kondisi lantai rumah yang dimiliki oleh informan. Adapun lantai rumah informan dapat dilihat pada tabel berikut:

Tabel 4.6Kondisi Lantai Rumah Informan

\begin{tabular}{ccccc}
\hline No & $\begin{array}{c}\text { Jenis Lantai } \\
\text { Rumah }\end{array}$ & Jumlah (Orang) & Persentase (\%) & Kategori \\
\hline 1 & Tegel & 1 & 4 & Tinggi \\
\hline 2 & Semen & 19 & 83 & Sedang \\
\hline 3 & Papan & 3 & 13 & Sedang \\
\hline 4 & Tanah & - & - & - \\
\hline & Jumlah & 23 & 100 & - \\
\hline
\end{tabular}

Sumber : Data Primer Diolah, 2018

Berdasarkan pada tabel diatas dapat diketahui bahwa informan yang menggunakan tegel untuk lantai rumah sebanyak 1 informan dengan jumlah persentase $4 \%$ dan yang menggunakan lantai semen sebanyak 19 orang informan dengan persentase $83 \%$, sedangkan yang menggunakan lantai papan sebanyak 3 informan atau sebesar $13 \%$. Hal ini menunjukan bahwa pada umumnya informan memiliki lantai rumah dari semen.

\section{Sumber penerangan rumah}

Sumber penerangan yang ada dirumah informan secara keseluruhan adalah listrik atau bersumber dari PLN. Untuk lebih jelasnya dapat dilihat pada tabel berikut:

Tabel 4.7Sumber Penerangan Rumah Informan

\begin{tabular}{ccccc}
\hline No & Sumber Penerangan & Jumlah (Orang) & Persentase $(\%)$ & Kategori \\
\hline 1 & Listrik & 23 & 100 & Tinggi \\
\hline 2 & Petronas & - & - & - \\
\hline 3 & Teplok & - & - & - \\
\hline & Jumlah & 23 & 100 & - \\
\hline
\end{tabular}

Sumber : Data Primer Diolah,2018

Berdasarkan tabel di atas, dapat dilihat bahwa semua informan $100 \%$ menggunakan alat penerangan yang bersumber dari Perusahaan
Listrik Negara (PLN) sebagai sumber penerangan rumah mereka. Akan tetapi sumber penerangan di kecamatan mowewe khususnya desa 
lapangisi hanya berfungsi pada malam hari saja.

\section{Sumber air bersih rumah}

Umumnya informan menggunakan ledeng/PDAM sebagai sumber air bersih untuk diminum, memasak, mandi,mencuci dan lainlain. Hal ini dapat dilihat pada tabel berikut:

Tabel 4.8Sumber Air Bersih Yang Digunakan Informan

\begin{tabular}{ccccc}
\hline No & Sumber Air & Jumlah (Orang) & Persentase $(\%)$ & Kategori \\
\hline 1 & PDAM & 23 & 100 & Tinggi \\
\hline 2 & Sumur & - & - & - \\
\hline 3 & Sungai & - & - & - \\
\hline & Jumlah & 23 & 100 & - \\
\hline & & Sumber: data primer diolah, 2018
\end{tabular}

Dari tabel di atas menunjukan bahwa dari 23 orang informan yang di teliti, keseluruhan telah menggunakan air yang

bersumber dari PDAM sebagai sumber airbersih untuk minum, memasak, dan mandi.

\section{Jumlah kamar rumah}

Tabel 4.9Jumlah Kamar Di Rumah Informan

\begin{tabular}{ccccc}
\hline No & Jumlah Kamar & Jumlah (Orang) & Persentase $(\%)$ & Kategori \\
\hline 1 & $\geq 4$ & 3 & 13 & Tinggi \\
\hline 2 & $2-3$ & 20 & 87 & Sedang \\
\hline 3 & 1 & - & - & - \\
\hline & Jumlah & 23 & 100 & - \\
\hline \multicolumn{5}{c}{ Sumber $:$ Data Primer Diolah, 2018} \\
\end{tabular}

Berdasarkan tabel di atas dapat di ketahui bahwa 20 informan yang memiliki jumlah $2-3$ kamar di rumah informan dengan persentase $87 \%$, sedangkan yang memiliki $\geq 4$ kamar tidur hanya 3 informan dengan persentase $13 \%$.

\section{Kondisi kesehatan informan}

Frekuensi anggota keluarga yang sakit selama 6 bulan terakhir

Kesehatan merupakan salah satu faktor yang paling penting dalam

Tabel 4.10Pernyataan Informan Mengenai Kondisi Kesehatan Keluarganya

\begin{tabular}{ccccc}
\hline No & $\begin{array}{c}\text { Kondisi } \\
\text { Kesehatan }\end{array}$ & Jumlah (Orang) & Persentase (\%) & Kategori \\
\hline 1 & Baik & 21 & 91 & Tinggi \\
\hline
\end{tabular}

kehidupan manusia. Karena dengan kondisi kesehatan yang baik maka aktifitas untuk menjalankan kehidupan sehari-hari dalam mencari nafkah akan berjalan dengan baik. Kondisi kesehatan meliputi kondisi fisik, mental dan lingkungan. Untuk lebih jelasnya mengenai tingkat kesehatan keluarga yang sakit selama 6 bulan terakhir dapat dilihat pada tabel berikut: 


\begin{tabular}{ccccc}
2 & Kurang Baik & 2 & 9 & Rendah \\
\hline Jumlah & 23 & 100 & - \\
\hline
\end{tabular}

Sumber : Data Primer Diolah 2018

Data diatas Nampak bahwa umumnya informan yaitu $91 \%$ mempunyai kondisi kesehatan yang baik. Namun demikian terdapat pula anggota keluarga informan yamg mengalami gangguan kesehatan yaitu sebesar 9\% yang mempunyai kondisi kesehatan yang kurang baik.

Dari penjelasan diatas, maka dapat dikatakan bahwa kondisi kesehatan masyarakat petani Desa Lapangisi relatif baik.Pada dasarnya masyarakat sudah mempunyai kesadaran betapa pentingnya hidup sehat.

\section{Tempat berobat}

Terkait dengan tempat berobat yang digunakan oleh masyarakat Desa Lapangisi, maka berikut ini disajikan tabel tentang tempat berobat informan adalah sebagai berikut:

Tabel 4.11 Tempat Berobat Informan

\begin{tabular}{ccccc}
\hline No & Tempat Berobat & Jumlah (Orang) & Persentase $(\%)$ & Kategori \\
\hline 1 & RSUD & - & - & Tinggi \\
\hline 2 & Pusksmas & 23 & 100 & Sedang \\
\hline 3 & Dukun & - & - & - \\
\hline & Jumlah & 23 & 100 & - \\
\hline
\end{tabular}

Sumber : Data Primer Diolah, 2018

Dari tabel tersebut keseluruhan informan umumnya menunjukan bahwa sebanyak 23 mereka berobat di puskesmas.

informan atau sebesar $100 \%$ dari

\section{Pembayaran pengobatan}

Tabel 4.12Jenis Pembayaran Pengobatan

\begin{tabular}{ccccc}
\hline No & Biaya Pengobatan & Jumlah (Orang) & Persentase (\%) & Kategori \\
\hline 1 & BPJS & 23 & 100 & Sedang \\
\hline 2 & Biaya Sendiri & - & - & - \\
\hline & Jumlah & 23 & 100 & - \\
\hline & & Sumber : Data Primer Diolah, 2018
\end{tabular}

Berdasarkan tabel diatas dapat diketahui bahwa, rata-rata informan memiliki kartu bpjs yang di pergunakan untuk pembayaran iyuran kesehatan di puskesmas.

\section{Kondisi ekonomi informan Produksi pertanian}

Terkait dengan produksi pertanian bahwa hasil panen tanaman pertanian masyarakat desa lapangisi, maka berikut ini disajikan tabel tentang hasil produksi pertanian informan adalah sebagai berikut: 
Tabel 4.13 Produksi pertanian

\begin{tabular}{ccccc}
\hline No & Jenis Lahan Pertanian & Jumlah (orang) & Persentase (\%) & Kategori \\
\hline 1 & Sawah & 13 & 57 & Tinggi \\
\hline 2 & Ladang & 6 & 26 & Sedang \\
\hline 3 & Kebun & 4 & 17 & Rendah \\
\hline & Jumlah & 23 & 100 & - \\
\hline
\end{tabular}

Sumber : Data Primer Diolah, 2018

Berdasarkan pada tabel diatas dapat diketahui bahwa informan yang memiliki jenis lahan pertanian sawah sebanyak 13 informan dengan jumlah persentase $57 \%$ dan yang memiliki jenis lahan pertanian ladang sebanyak 6 orang informan dengan persentase $26 \%$, sedangkan yang memiliki jenis lahan pertanian kebun sebanyak 4 informan atau sebesar $17 \%$. Hal ini menunjukan bahwa pada umumnya informan memiliki memiliki jenis lahan pertanian sawah.

\section{Distribusi Produk Pertanian}

Terkait dengan distribusi produk pertanian bahwa masyarakat Desa Lapangisi pada umumnya mendistribusikan hasil pertaniannya ke pasar-pasar yang ada di daerah Provinsi Sulawesi Tenggara dengan harga yang standar.

\section{Pendapatan informan}

Dari penelitian yang telah dilakukan bahwa pendapatan yang di terima oleh informan sangatlah berfariasi, untuk lebih jelasnya dapat di lihat pada tabel di bawah:

Tabel 4.14Tingkat Pendapatan Informan Setiap Bulanya

\begin{tabular}{ccccc}
\hline No & $\begin{array}{c}\text { Jumlah pendapatan setiap bulan } \\
\text { (RP) }\end{array}$ & $\begin{array}{c}\text { Jumlah } \\
\text { (orang) }\end{array}$ & persentase $(\%)$ & Kategori \\
\hline 1 & Rp. $2.500 .000-4.000 .000$ & 14 & 61 & Tinggi \\
\hline 2 & Rp. $1.800 .000-2.500 .000$ & 6 & 26 & Sedang \\
\hline 3 & $\leq$ Rp. 1.800 .000 & 3 & 13 & Rendah \\
\hline & Jumlah & 23 & 100 & - \\
\hline
\end{tabular}

Sumber : Data Primer Diolah, 2018

Berdasrkan tabel diatas dapat diketahui bahwa pendapatan pokok yang di peroleh informan berdasarkan klarifikasi pendapatan $\leq$ Rp. 1.800 .000 yaitu sebanyak 3 informan dengan persentase $13 \%$, pendapatan Rp. $1.800 .000-2.500 .000$ sebanyak 6 informan dengan persentase $26 \%$, sedangkan pendapatan Rp. $2.500 .000-$ 4.000.000 yaitu sebanyak 14 informan dengan persentase $61 \%$.

\section{Pembahasan Penelitian}

Berdasarkan hasil penelitian mengenai kondisi sosial masyarakat petani Desa Lapangisi Kecamatan Mowewe Kabupaten Kolaka Timur menunjukan kondisi sosial ekonomi yang tergolong sedang, hal ini dapat di lihat pada indikator yang terdapat di dalamnya mulai dati tingkat pendidikan, perumahan, kesehatan danpendapatan. Dari keempat indikator ini yaitu bahwa pendidikan sebahagian besar informan telah menyelesaikan pendidikan formalnya dan ini dapat meningkatkan taraf 
intelektualitasnya dan partisipasi masyarakat terhadap pembangunan, sehingga berdasarkan indikator penilaian kondisi pendidikan di Desa Lapangisi Kecamatan Mowewe Kabupaten Kolaka Timur di kategorikan masi rendah dengan asumsi bahwa pendidikan formal yang di selesaikan/ditamatkan rata-rata hanya tamatan Sekolah Dasar (SD) dan Sekolah Menengah Pertama (SMP).

Kemudian dilihat dari kondisi perumahan informan masyarakat petani Desa Lapangisi, dari 24 jumlah informan ada 2 informan yang masi tinggal bersama orang tua atau masi numpang bersama keluaga. Sehingga perumahan informan masyarakat petani Desa Lapangisi berada pada kriteria sedang hal ini juga ditunjukan dengan yang ada di dalamnya sepetri status kepemilikan rumah, jenis lantai rumah, jenis dinding rumah, jenis atap rumah, sumber penerangan rumah dan sumber air bersih yang ada dirumah informan.

Terkait dengan kondisi kesehatan, telah menunjukan hasil yang baik dimana masyarakat petani sadar bahwa pentingnya hidup sehat dan menjaga kebersihan lingkungan rumah, karena jika terkena penyakit masyarakat tidak bisa manjalankan aktifitasnya seperti biasanya. Di saat terserang penyakit informan lebih memilih berobat ke puskesmas karena jarak antantara puskesmas sangat terjangkau dari Desa Lapangisi, pelayanan yang di tawarkan juga sangat baik dan cara pengobatanya juga praktis.

$$
\text { Membahas tentang }
$$
pendapatan bahwa seluruh informan, baik informan kunci maupun informan pokok untuk membiayai kehidupan rumah tanngganya tidak bisa hanya berharap pada hasil panen padi saja akan tetapi mereka mencari pekerjaan sampingan diantaranya sebagai ojek sawah, beternak dan lain-lain. Dan hal ini di dasarkan pada indikator penilaian dapat di kategorikan sedang karena pendapatan yang diterima informan setiap bulannya rata-rata sebesar Rp. 1.800.000 sampai Rp 2.500.000.

Berdasarkan pada hasil
penelitian diatas,
menggambarkan bahwa tingkat pendapatan informan dapat di katakan sedang, karena tingkat pendapatan selalu sejalan dengan pengeluaran dalam rumah tangga informan. Sehingga untuk mengukur ingkat konsumsi informan cukup dilihat pada tingkat pendapatan yang di peroleh setiap bulannya.

\section{KESIMPULAN}

berdasarkan hasil penelitian dan pembahasan dengan menggunakan indikator Badan Pusat Statistik (BPS) diketahui bahwa petani di Desa Lapangisi Kecamatan Mowewe Kabupaten Kolaka Timur, dapat disimpulkan bahwa:

1. Kondisi sosial masyarakat dengan tingkat pendidikan dalam kategori rendah atau sebesar $(62 \%)$ namun masyarakat sudah memiliki rumah sendiri.

2. Kondisi ekonomi bahwa informan dari segi penghasilan di dominasi oleh penghasilan tinggi dengan jumlah persentase sebesar (61\%). Jenis lahan pertanian sawah lebih mendominasi dengan jumlah persentase $57 \%$. Kemudian hasil produksinya didistribusikan ke pasar lokal yang ada di daerah Provinsi Sulawesi Tenggara dengan harga yang standar. Dan konsumsi yang paling banyak di keluarkan oleh informan adalah biaya 
makanan kemudian disusul dengan biaya lain-lain.

3. Berdasarkan indikator kondisi sosial ekonomi menurut badan pusat statistik secara umum di ketahui bahwa taraf hidup masyarakat petani Desa Lapangisi Kecamatan Mowewe Kabupaten Kolaka Timur adalah tergolong kategori sejahtera.

Beradasarkan kesimpulan di atas, maka peneliti memberikan saran :

a. Bagi masyarakat di harapkan agar dapat meningkatkan lagi pendapatan perbulannya, sehingga dapat meningkatkan kondisi sosial ekonimi keluarganya terutama di tingkat pendidikan, perumahan dan kesehatan.

b. Kepada pemerintah daerah, kiranya dapat lebih memperhatikan kondisi sosial masyarakat petani di Desa Lapangisi Kecamatan Mowewe Kabupaten Kolaka Timur melalui bantuan pembinaan usaha ekonomi produktif terutama bagi kelompok tani yang belum memiliki alat pertnian dan lain-lain sehingga mereka dapat meningkatkan taraf hidup kearah yang lebih baik lagi.

\section{DAFTAR PUSTAKA}

Abrams, Charles. (1964). Man's Struggle For Shelter In An Urbanizing World.London : Cambridge.

A.T. Mosher. 1968. Menggerakkan dan Membangun Pertanian, Jakarta : Jayaguna,

Arikunto. 2005. Metode Penelitian Kualitatif. Jakarta: Sagung Seto.
Dalyono.2005. psikologi pendidikan. Rineka Cipta. Jakarta

Dyckman, Thomas R., Roland E. Dukes, Charles J. Davis, 2002. Akuntansi Intermediate, Edisi Kesepuluh, Jilid I, Terjemahan EmilSalim. Jakarta: Erlangga

Ekawarna, 2010, Pengantar Teori Ekonomi Makro, Jakarta:Gaung persada (Gp) Press.

Melly. 2001. Wanita Dalam Struktur Sosial Di Indonesia, Rajawali Pers Jakarta

Niswonger, Reeve, Warren, dan Fess, 1999, Prinsip-prinsip Akuntansi, edisi kedua, Yogyakarta: Andi Offset.

Purwanto.1987. Ilmu Pendidikan Teoritis dan Praktis.Penerbit PT. Remaja Rosda Karya. Bandung

Soekanto.1988. Teori Sosiologi Tentang Dinamika Perubahan Sosial.Ghalia. Jakarta.

Suparmoko, 2008, Ekonomi Sumberdaya Alam dan Lingkungan (Suatu Pendekatan Teoritis), BPFE, Yogyakarta.

Syam.1980. Pengantar Dasar-Dasar Pendidikan. Surabaya. Usaha Nasional.

Yudhohusodo, Siswono. (1991). Rumahuntuk Seluruh Rakyat. Jakarta:Yayasan Padamu Negeri. 